Bulletin of the AAS • Vol. 54, Issue 1 (Obituaries, News \& Commentaries, Community Reports)

Joseph F. Zelle (1912-2009)

\title{
Christopher Cumo
}

Published on: Feb 11, 2022

License: Creative Commons Attribution 4.0 International License (CC-BY 4.0). 
Joseph Frank Zelle, age 97, radio engineer, died on July 11, 2009 in Euclid Hospital in Cleveland, Ohio of sepsis. He used his talents and time for the betterment of radio and Saint Vitus Church in Cleveland. Joining the Ohio Academy of Science in 1974, Zelle became an emeritus member in 1991.

The son of Mihael Zele and Ivana (Tekavec) Zele (the last name was elongated to Zelle), Joseph Frank Zelle was born on February, 25, 1912. A Catholic, Zelle was baptized at Saint Vitus Church 3 March 1912. His godparents were Frank and Franciska Hribar. Confirmed February 25, 1921 at Saint Vitus, Zelle received First Holy Communion April 3, 1921. His sponsor was Frank Primozic, Sr.

Zelle's early education was at Case Elementary School (1918-1920), Saint Vitus School (1920-1926), and Willson Junior High School (1926-1927), all in Cleveland. He graduated from Cathedral Latin School (1931). Receiving an A.B. from John Carroll University (1939), Zelle majored in English and minored in Philosophy. He earned an M.A. from Western Reserve University (1942), where he majored in English and minored in German. Attending Capitol Radio Engineering Institute in Washington, D.C., Zelle studied radio broadcast engineering (1942-1947). He studied physics and mathematics at Western Reserve University (1950-1952) and at John Carroll University (1951-1966). Zelle held a first-class license in radiotelephony, a second-class license in radiotelegraphy, and an extra class license in amateur radio, all from the Federal Communications Commission. Zelle was also a professional engineer with a specialty in electrical engineering.

A studio engineer at radio station WGAR (summer 1941) in Cleveland, Zelle was a studio and transmitter engineer at the Columbia Broadcasting System (CBS) between September 1941 and September 1944 in New York City. Zelle also worked for the Office of War (OWI) now the Voice of America (September 1944 - December 1945). He was a radio consultant engineer between January 1946 and his retirement. At radio stations WABQ and WXEN in Cleveland, Zelle was a standby engineer, at radio station WCLV in Cleveland a chief engineer and at radio station WCVJ in Jefferson, Ohio vice president and director of engineering. In Cleveland, he taught electronics at Max Hayes Trace School, electronics and physics at the Cleveland Technicians School, Slovenian at Cleveland State University, and electronics and physics at Cuyahoga Community College. Zelle was a technical writer at the Cleveland Institute of Radio Electronics (1946-1947) and was a radio announcer at radio station WERE (1949-1951) in Cleveland, where he hosted a Slovenian nationality program. He was also an 
announcer at radio station WCLV and at radio station WCVJ in Jefferson, Ohio. As a consultant, he worked for Pierce, Hutton and Fox of Cleveland; Carl E. Smith Radio Consulting Engineers of Cleveland; McNary and Wrathall Radio Consultants of Washington, D.C.; Lynne C. Smeby Radio Consultant of Washington, D.C.; and Colonel E. Wilson of Washington, D.C. Among his assignments Zelle took field strength measurements on radio station WISR in Butler, Pennsylvania; conducted field strength survey for radio station WWJ in Detroit; took measurements of antenna impedance at radio station WCMW in Canton, Ohio; and calculated and plotted vertical field intensity for radio station WHKC in Columbus, Ohio.

Zelle was active in numerous organizations. He was a life member of the American Radio Relay League, the Quarter Century Wireless Association, and the Ohio Retired Teachers Association. He was a senior member of the Institute of Electrical and Electronics Engineers and a member of the American Institute of Electrical Engineers, the Institute of Radio Engineers, the American Physical Society, the American Astronomical Society, the American Mathematics Society, the Mathematical Association of America, the American Association for the Advancement of Science, the New York Academy of Sciences, the Northeast Ohio Commodore Users' Group, the American Slovenian Catholic Union, the Saint Vitus Holy Name Society, the North Shore Animal League, the 700 Club, the Friends of the Slovenian National Home, and the Slovenian Research Center. A member of the executive committee for the Slovenian Chapel in the National Cathedral of the Immaculate Conception in Washington, D.C., Zelle was vice president of the Catholic Mission Aid in Cleveland and was founding president of the Saint Vitus Alumni in Cleveland.

Active in the theater, Zelle served as stage manager for a number of productions, many of them at Saint Vitus School Auditorium. He also made documentary films of his church and the Slovenian Cultural Garden. Zelle was the author of numerous articles, poems and translations. By his own account Zelle was one of the first to detect the signals from the Soviet satellite Sputnik in 1957. He also had interests in computers and photography.

Predeceased by his parents, sisters Emily and Sophia, and brother Rudy, Joseph Frank Zelle is survived by several cousins. Zelle is buried at Calvary Cemetery in Cleveland, Ohio.

Adapted and reproduced with permission from the The Ohio Academy of Science. 
